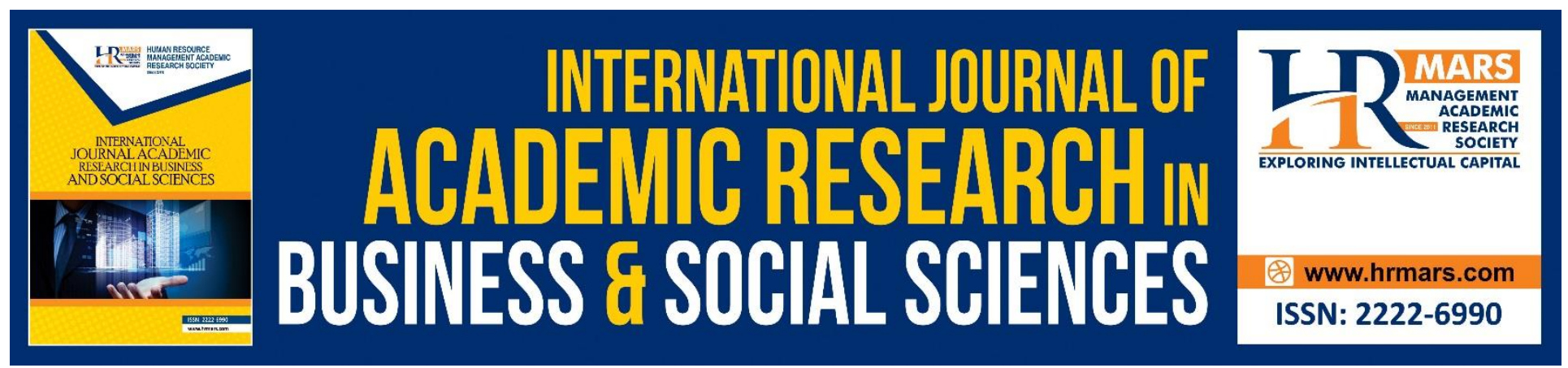

\title{
Promoting Good Citizens through Service-Learning Engagement in Multi-Ethnic Malaysia
}

Noor Banu binti Mahadir, Tan Bee Piang, Zuraini binti Jamil @ Osman

To Link this Article: http://dx.doi.org/10.6007/IJARBSS/v9-i1/5493 DOI: $10.6007 /$ IJARBSS/v9-i1/5493

Received: 17 Dec 2018, Revised: 23 Jan 2019, Accepted: 07 Feb 2019

Published Online: 09 Feb 2019

In-Text Citation: (Mahadir, Piang, \& Osman, 2019)

To Cite this Article: Mahadir, N. B. binti, Piang, T. B., \& Osman, Z. binti J. @. (2019). Promoting Good Citizens through Service-Learning Engagement in Multi-Ethnic Malaysia. International Journal of Academic Research in Business and Social Sciences, 9(1), 940-949.

Copyright: (C) 2019 The Author(s)

Published by Human Resource Management Academic Research Society (www.hrmars.com)

This article is published under the Creative Commons Attribution (CC BY 4.0) license. Anyone may reproduce, distribute, translate and create derivative works of this article (for both commercial and non-commercial purposes), subject to full attribution to the original publication and authors. The full terms of this license may be seen

at: $\underline{\text { http://creativecommons.org/licences/by/4.0/legalcode }}$

Vol. 9, No. 1, 2019, Pg. 940 - 949

http://hrmars.com/index.php/pages/detail/IJARBSS

JOURNAL HOMEPAGE

Full Terms \& Conditions of access and use can be found at http://hrmars.com/index.php/pages/detail/publication-ethics 


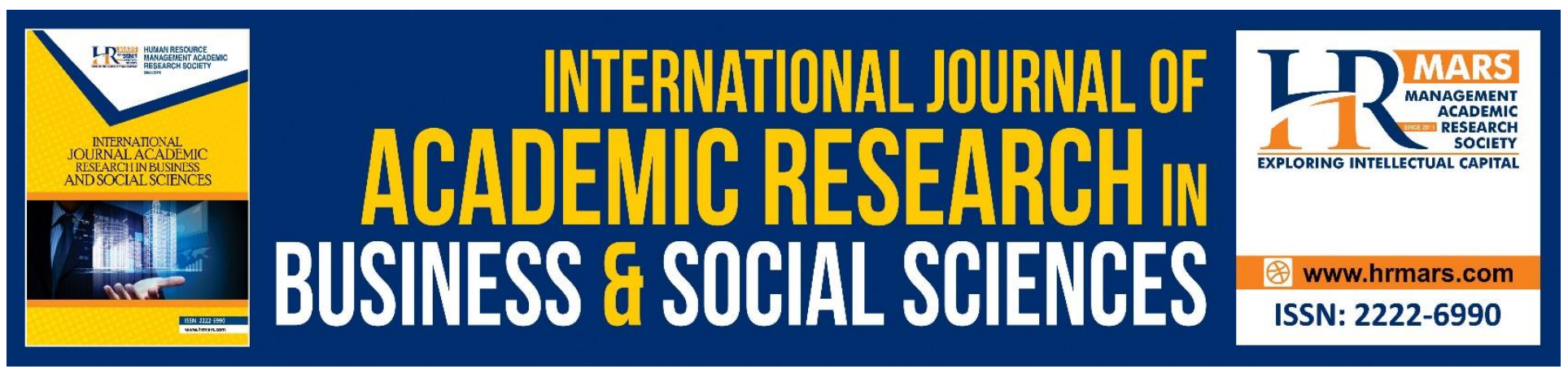

\title{
Promoting Good Citizens through Service-Learning Engagement in Multi-Ethnic Malaysia
}

\author{
Noor Banu binti Mahadir \\ Sultan Idris Education University, Malaysia \\ Tan Bee Piang \\ Sultan Idris Education University, Malaysia \\ Zuraini binti Jamil @ Osman \\ Sultan Idris Education University, Malaysia
}

\begin{abstract}
Citizenship education is not just a matter of learning the basic facts about institutions and procedures of political life, but also understanding about politics, the law and the economy, and the civic skills to engage effectively and responsibly in public and democratic life. To meet these requirements, various pedagogical approaches including service-learning, community service and volunteerism have been designed. Service-learning in Civics and Citizenship Education (CCE) requires the students to involve themselves in the community, either within the school community or the neighborhood community. This paper attempts to discuss the use of service learning as a learning tools to promote a participative citizen in multi-ethnic Malaysia.
\end{abstract}

Keywords: Good Citizens- Service Learning- Citizenship Education-Multi-Ethnic Malaysia.

\section{Introduction}

Citizenship education is not just a matter of learning the basic facts about institutions and procedures of political life. It also involves acquiring a wide range of dispositions, virtues and closely linked to the practices of democracy (Balakrishnan, 2010). Citizenship education not only teaches civic knowledge, but also understanding about politics, the law and the economy, and the civic skills to engage effectively and responsibly in public and democratic life. Therefore, citizenship education is fundamental to living in a democratic society. For example, the concerns about citizenship education in Europe related to the essential fabric of democratic societies: their values, the forms of social interaction and organization, and the perceived threats to them, and to the consequences and the management of changes in societies (Cecchini, 2004). Evidence suggested that the importance of democratic citizenship education is varied; for some, a commitment to democracy is a promise to 
protect liberal notions of freedom, while for others democracy is primarily about equality or equality of opportunity. For some, good citizens in a democracy are volunteers, while for others good citizens take an active role in political processes by voting, protesting, and working on political campaigns. To make this aspiration a reality, citizens have to be participative and active and be willing to have an influence in public life (Crick, 1998), various pedagogical approaches including service-learning, community service and volunteerism have been designed.

\section{Good Citizens Framework}

The good citizens framework proposed by (Westheimer \& Kahne, 2004a) that are: (1) the personally responsible citizen, (2) the participatory citizen and (3) justice oriented citizens can be quite valuable as a foundation framework around which to build a curriculum, including assessment as well as pedagogy, in civics and citizenship education in the new millennium. (Westheimer \& Kahne, 2004b). Westheimer and Kahne (2004b) developed a framework from their analysis of citizenship education curriculum promoting the democratic citizenship in the United States. The three kind of citizens envisioned by the school, which they found as answers to the question 'what kind of citizen do we need to support an effective democratic society were the personally responsible citizen; the participatory citizen and the justice oriented citizen. Westheimer and Kahne (2004b) addressed the idea that each of these visions of citizenship reflects a relatively distinct set of theoretical and curricular goals' (p. 241). They claimed that these visions are not cumulative and adopt different visions in achieving a good citizenship education programmes to produce a good citizens in democratic society

\section{The Personally Responsible Citizen}

The personally responsible citizens act responsibly in his or her community by, for example, picking up litter, giving blood, recycling, obeying laws and staying out of debt'(Westheimer \& Kahne, 2004b). Personally responsible citizens are aware of social problems in their communities and volunteer occasionally to meet community needs. This citizen vision includes individuals who seek to improve society through direct community service but who do not have a full grasp of the underlying causes of social problems. This type of citizen contributes to food or clothing drives when asked and volunteers to help those less fortunate whether in soup kitchens or a center for the elderly. Explicitly this vision promotes character building and personal responsibility. The curriculum and programs promote engaging in volunteer activities in developing the character buildings.

\section{The Participatory Citizen}

The participatory citizen dimension focuses on 'actively participation in civic affairs and the social life of the community at the local, state and national level.' (Westheimer \& Kahne, 2004b, p. 241). Proponents of this vision emphasize preparing students to engage in collective community based efforts by teaching the students how the government and community-based organizations work and training them to plan and participate in organized efforts to care for people in need. Differ from a personally responsible citizen that would contribute cans of food for the homeless the participatory citizens might organize the food drive. Participatory citizens are knowledgeable about community issues and are actively engaged in their communities toward the goal of creating societal change 
(Westheimer \& Kahne, 2004a). Beyond personally responsible citizens, participatory citizens take more leadership roles within their communities while remaining involved in direct community service.

\section{The Justice Oriented Citizen}

The justice oriented citizen - 'the perspective that is least commonly pursued' which is based on the claim 'the effective democratic citizens need opportunities to analyze and understand the interplay of social, economic and political forces' (Westheimer \& Kahne, 2004b). Justice oriented citizens address social issues by determining their root causes and actively working to change systems in society that perpetuate social injustice. The aspect of 'collective works related to issues in the community 'is sharing the same vision with the participatory citizen, but reflect critically and seek for social change make it different.

Among these three visions, the personally responsible citizenship is most accepted and practiced in most of the citizenship education curriculum in United States. However, Westheimer and Kahne claimed that it is not enough in response to the challenges of educating democratic citizens. They do agree on the importance of personality character traits and vision 'patriotism' and' obeying the laws' that flow from democratic structures but democratic citizenship in more beyond that that whereby some of these them are not essentially about democracy.

\section{Service learning and civic engagement}

A curriculum focusing on the social responsibilities of education must include situations relevant to the problems of living together (Dewey, 2004). Through the teaching of civics and citizenship, active learning takes place where students are able to apply what they acquire in the classroom to the implementation of citizenship projects. Service-learning provides students with the opportunity to engage in structured activities that are intentionally designed to enhance student learning and civic responsibility, while addressing community needs (Jacoby, 1996). (Westheimer \& Kahne, 2004b) addressed the relationship between service-learning and citizenship development. They argue that service-learning more than other pedagogies or extra-curricular activities has the potential to significantly increase civic responsibility.

Service-learning is a pedagogical practice and learning method that integrates service and academic learning. It aims to promote an increased understanding of course content while helping students to develop the knowledge, skills, and cognitive capacities to deal effectively with the complex social issues and problems that communities face. It is an approach that emphasizes reflection and fieldbased learning as a way to engage the learner personally with the curriculum (Eyler \& Giles Jr, 1999) a pedagogy, service-learning emphasizes meaningful student learning through applied, active, project-based learning that draws on multiple knowledge sources (academic, student knowledge and experience, and community knowledge) and provides students with ample opportunities for ethical and critical reflection linked to practice (Eyler \& Giles Jr, 1999). 
Service-learning is becoming acknowledged as one of the most useful pedagogical tools in promoting civic responsibilities, social justice and civic engagement (Billig, Root, \& Jesse, 2005). Service-learning has long been associated with important civic learning outcomes, like enhancing students' engagement with the community and developing their sense of civic responsibility. Evidence suggests that the promotion of service-learning, 'as opposed to traditional classroom learning, is a more successful approach to inculcating active citizenship and civic duty' (Brown as cited in Birdwell, Scott, \& Horley, 2013, p. 186).

Studies of students' participation in service-learning projects or community service indicates positive outcomes of social responsibility, personal empowerment and a commitment to promote racial understanding, as well as educational benefits (Sax, Astin, \& Avalos, 1999). Soukup (1996), stated that service-learning was the best locale to provide students with 'first-hand experience of diversity and multiculturalism' (p. 9), by giving students the opportunity to mix with people different from themselves.

Several researchers have found that involvement in service-learning fosters citizenship and develops a sense of political efficacy in the students involved (Drane, 2001; Parker \& Altman Dautoff, 2007). Students who participate in service-learning have shown significant increases in the belief that they could make a difference, and have an interest in future volunteer service, have plans to become involved in helping careers, and have a greater ability to get along with people of different backgrounds (Gallini \& Moely, 2003).

Eyler, Giles Jr, \& Braxton (1997), large scale study provides a more in-depth analysis of these results. The Comparing Models of Service-learning project was a national study in the United States of America of the impact of service-learning programs on students' citizenship values, skills, attitudes, and understanding. Fifteen hundred 18 students at thirty colleges and universities completed surveys at the beginning and end of the service-learning experience. Students were asked to compare their service-learning experience with their experiences in other classes by asking students to assess the quality of each course, their learning, intellectual stimulation, and motivation to work hard. The researchers focused on students' assessments of their citizenship skills, on their confidence that they could and should make a difference in their communities, on their community-related values and on their perceptions of social problems and social justice. These constructs were selected because they had been identified as the most frequently expressed goals of service-learning programs (Eyler, Giles \& Braxton, 1997). Generally, Eyler, Giles, \& Braxton found that participation in high quality servicelearning leads to the values, knowledge, skills, sense of efficacy, and commitment that underlie citizenship. Among the program characteristics of service-learning that they found made a difference in education for effective citizenship were: placement quality, application, reflection activities, diversity, and community voice.

\section{Citizenship Education and Service learning in Malaysia}

Civics as a school subject was first introduced in 1953 as the manifestation of the emphasis on civic training for all schools, in the Education Report of 1952 (Sidin \& Aziz as cited in Jaffar \& Habib 1992). 
Subsequently, the Education Report of 1956, a year before Malaysian independence, also stressed the importance of Civics as a compulsory subject for citizenship training, especially towards social solidarity and social cohesion among multi-ethnic Malaysians. Therefore, Civics as a school subject involved basically the teaching of the National Ideology to achieve the objectives of fostering loyalty and patriotism, tolerance of others, developing self-reliance, innovative attitudes, correct social conducts, good behaviour and morality (Tejima, n.d.).

The Civics syllabus was revised in 1976 in line with the themes of Rukun Negara (National Ideology) that was formulated in 1970 and aimed to achieve its goals (Barone, 2002). The objectives of Civics were to: (a) foster a spirit of patriotism, (b) inculcate an attitude of tolerance towards other races and groups, (c) develop independence and self-reliance, (d) develop a positive attitude towards change and (e) inculcate good character (Hashim \& Tan, 2009). Nevertheless, Civics was withdrawn when the government introduced moral education in 1983, and this led to complaints from the Congress of Teachers' Union, observing that due to the withdrawal of civics education, the younger generation had become less civic-conscious and responsible, showed less respect to diversity and lack of awareness of national issues. Consequently, it was restored into the curriculum in (Hashim \& Tan, 2009; Ministry of Education Malaysia, 2004).

A refurbishment of the education system took place in the 1980s and with it, the subject was replaced with another subject called "Man and Nature", where the elements of civics were embedded in the primary school curriculum (Farouk \& Husin, 2011). While the previous subject focused on civicsrelated matters, the new subject combined Science, History, Geography and Health, which, prior to this change, were taught as separate subjects (Barone, 2002). Although the aim was to embed civics knowledge across other curricular subjects, this resulted in lessening the focus on civic education or civic elements. Thus, while from the 1950s through to the 1970 s civic education was treated as a stand-alone subject with clear objectives, from the 1980s through to the late 1990s, civics education was left aside for more core subjects, which were more aligned with the country's aspiration for economic development (Kamaruddin Jaafar, 1992).

In line with the National Education philosophy apprehended by the government, that views education as a tool for integration and realizing social harmony and mutual understanding, the syllabus of civic education in Malaysia exposes students to the cultures of the various ethnic groups in the country (Farouk \& Husin, 2011). Civics education is also used to spread the ideas of/from the ruling class of the accepted ways of being a Malaysian. This is achieved by inspiring a sense of loyalty to the country. The re-introduction of civic education into the curriculum is still grounded in this philosophy, despite being envisioned as a curriculum that will create active citizenship among students. While this new outlook on civic education is a positive change, there are challenges in its implementation (Balakrishnan, 2010). Therefore, Citizenship Education in Malaysia used to focus on civic knowledge and on patriotism, and the importance of the structure and type of government (Ministry of Education, Malaysia, 2004). This might be expressed as 'minimal citizenship education', which stresses the basic knowledge of laws; systems of government and the basic principles of the constitution; and individual rights and obligations. Students were required to memorize symbolic 
events, anthems and facts of national importance, and the core ideas and ideals of citizenship education were located and embedded in such subjects as Moral Studies, Malaysian Studies, Islamic Studies, Social Studies and History (Ministry of Education, Malaysia, 1994, 2002, as cited in Bajunid, 2008).

Subsequently, education in Malaysia is based on an exam-oriented system, meaning that subjects that are taught but not examined, including civics and citizenship education, have to compete with other subjects such as mathematics, Bahasa Malaysia (Malay language), English, biology and physics for students' attention and teachers' commitment (Farouk \& Husin, 2011). In an attempt to make the subject interesting and relevant, current civics and citizenship education focuses on 'education for citizenship and education through citizenship' by encouraging service-learning and by taking the subject out of the classroom (Balakrishnan, 2010).

The new Citizenship and Citizenship Education (CCE) policy aims 'to make students realize their roles, rights and responsibilities towards society and the country and to develop society and citizens who are united, patriotic and able to contribute towards a harmonious society, country and world' (Curriculum Development Centre, 2005, p. 2). The teaching and learning of CCE should emphasize on hands-on activities both inside and outside the classroom. Therefore, it could be said that besides learning civics knowledge, students are supposed to be involved in hands-on or active learning. Debates, discussion and role-play are some of the activities suggested in the syllabus (Ministry of Education Malaysia, 2004).

In the new Civic and Citizenship Education policy (CCE) 2005, the Citizenship Project (service-learning) was introduced to promote the development of participative and responsible citizens. Servicelearning forms one of the most important elements of the curriculum. At both levels students have to participate in a minimum 10-hour service-learning project during each school year. The objectives of service-learning in Civic and Citizenship Education in Malaysia are to enable students to apply the knowledge, skills and values gained in civic and citizenship education outside the classroom, to contribute towards the well-being of the family, school and community and to foster patriotism, caring and promote a sense of responsibility towards family, school and community (Bajunid, 2008; Ministry of Education Malaysia, 2004). Themes for the service-learning project are suggested in the syllabus, which for a Form Two (year 2) secondary school project is 'Living in Society'; a Form Three (year 3) project is 'Malaysian Diverse Cultural Heritage' and a Form Four (year 4) project is 'Malaysian Sovereignty'. Among the community projects suggested in these documents are helping elderly people in their homes, volunteering at the homes of special needs children or orphanages, organizing a Malaysian multicultural exhibition, undertaking Malaysian multi-ethnic cultural performances or exhibitions on the meaning of independence, and researching the contribution of Malaysia's leaders. Students are given the opportunity to discuss and decide on the activities that they would like to undertake. A simple strategy for implementing the community service project, which includes planning, practical work, reflection, reporting and giving acknowledgements is also provided in these syllabus specifications (CDC)., 2005). 
Civics and Citizenship Education curriculum in Malaysia was formed within the ideals articulated in UNESCO 'Learning To Be', emphasizing the four pillars of learning: learning to know, learning to do, learning to live with each other and learning to be, which emphasis on civic knowledge, skills and values (Delors, 1996). Therefore, Civics and Citizenship Education is not to be confined to civics lessons in the classroom alone. It should be of an integral part of all instructions and activities the students engage in during their school hours as well as during co-curricular activities, and outside school hours where students will have the opportunity to engage in community services. To encourage civic skills, teachers are expected to use various teaching methods to develop the three components of civic education. Service-learning, as one teaching strategy, seeks to give the students the opportunity and experience to engage with the community.

\section{Conclusion}

One of the teaching strategies that engaging students in civic engagement is through service learning. Service learning has long been associated with important civic learning outcomes like enhancing students' engagement with the community and developing their sense of civic responsibility (Hurd, 2006). Evidence suggests that the promotion of 'service learning', as opposed to traditional classroom learning, is a more successful approach to inculcating active citizenship and civic duty (Brown, 2012).

In particular to multi-ethnic Malaysia case, throughout the service-learning placement, the student learnt about other unheard minority voices. They realized that there are others who are also less recognized, less respected and less acknowledged as citizens in multi-ethnic Malaysia Further, Noor Banu Mahadir, 2017, study suggested that service-learning can be promote as a mechanism for encouraging interactions across boundaries and a deeper understanding of others. The students' involvement in service-learning enables them to not only develop themselves on a personal level, but also to contribute to their communities as citizens.

\section{Acknowledgement}

The authors wish to thank the Universiti Pendidikan Sultan Idris (UPSI) for funding this research Under GPU 2015-0062-106-01

\section{Corresponding Author}

Noor Banu binti Mahadir, Sultan Idris Education University, Malaysia.

Email: noor.banu@fsk.upsi.edu.my

\section{References}

Bajunid, I. A. (2008). The Building of a Nation and Ideas of Nationhood: Citizenship Education in Malaysia. In Citizenship Curriculum in Asia and the Pacific (pp. 127-146). Springer.

Balakrishnan, V. (2010). The development of moral education in Malaysia. Asia Pacific Journal of Educators and Education, 25, 89-101.

Barone, T. N. (2002). Civic Education and Citizenship in Malaysian Education.

Billig, S., Root, S., \& Jesse, D. (2005). The Impact of Participation in Service-Learning on High School Students' Civic Engagement. Elements (Vol. 33). 
INTERNATIONAL JOURNAL OF ACADEMIC RESEARCH IN BUSINESS AND SOCIAL SCIENCES

Vol. 9, No. 1, Jan, 2019, E-ISSN: 2222-6990 @ 2019 HRMARS

Birdwell, J., Scott, R., \& Horley, E. (2013). Active citizenship, education and service learning. Education, Citizenship and Social Justice, 8(2), 185-199.

Cecchini, M. (2004). Education for democratic citizenship in Europe: Concepts and challenges for action. In NECE Conference.

Crick, B. (1998). Education for citizenship and the teaching of democracy in schools. Final report, 22 September 1998.

Delors, J. (1996). Report to UNESCO on Education for the 21st Century-Learning: The Treasure Within. UNESCO, Paris.

Dewey, J. (2004). Democracy and education. Courier Corporation.

Drane, D. D. (2001). The relationship between service learning and self-reported civic outcomes of college students based on selected demographic variables.

Eyler, J. (1997). Report of a National Study Comparing the Impacts of Service-Learning Program Characteristics on Post Secondary Students.

Eyler, J., \& Giles Jr, D. E. (1999). Where's the Learning in Service-Learning? Jossey-Bass Higher and Adult Education Series. ERIC.

Eyler, J., Giles Jr, D. E., \& Braxton, J. (1997). The impact of service-learning on college students. Michigan Journal of Community Service Learning, 4, 5-15.

Farouk, A. F. A., \& Husin, A. (2011). Civic Education in an Emerging Democracy: Students' Experiences in Malaysia's Projek Warga. Asian Social Science, 7(3), 154.

Gallini, S. M., \& Moely, B. E. (2003). Service-learning and engagement, academic challenge, and retention. Michigan Journal of Community Service Learning, 10(1).

Hashim, R., \& Tan, C. (2009). A hyphenated identity: Fostering national unity through education in Malaysia and Singapore. Citizenship Teaching and Learning , 5(1), 46-59.

Hurd, C. A. (2006). Is service-learning effective?: A look at current research.

Jacoby, B. (1996). Service-learning in today's higher education. Service-Learning in Higher Education, 3-25.

Kamaruddin Jaafar, H. H. (1992). Isu-isu dalam Pendidikan Sivik. Kuala Lumpur: Institut Kajian Dasar.

Kamarudin Jaffar \& Hazami Habib. (1992). Isu-isu dalam Pendidikan Sivik: Ke arah kecemerlangan. Kuala Lumpur: Nurin Enterprise.

Ministry of Education Malaysia. (2004). The Development of Education. Kuala Lumpur.

Noor Banu Mahadir. (2017). Citizenship in multi-ethnic Malaysia: An investigation of Student Teachers' Understandings, Values and Beliefs. University of Edinburgh, Scotland.

Parker, B., \& Altman Dautoff, D. (2007). Service-learning and study abroad: Synergistic learning opportunities. Michigan Journal of Community Service Learning, 13(2).

Sax, L. J., Astin, A. W., \& Avalos, J. (1999). Long-term effects of volunteerism during the undergraduate years. The Review of Higher Education, 22(2), 187-202.

Soukup, P. A. (1996). Inviting Others To Take the Helm: Service-Learning and the Marginated Community.

Tejima, M. (n.d.). Development and Challenge: Citizenship Education in Malaysia.

Westheimer, J., \& Kahne, J. (2004a). Educating the "good" citizen: Political choices and pedagogical goals. Political Science and Politics, 37(02), 241-247.

Westheimer, J., \& Kahne, J. (2004b). What kind of citizen? The politics of educating for democracy. 
INTERNATIONAL JOURNAL OF ACADEMIC RESEARCH IN BUSINESS AND SOCIAL SCIENCES Vol. 9, No. 1, Jan, 2019, E-ISSN: 2222-6990 @ 2019 HRMARS

American Educational Research Journal, 41(2), 237-269. 